\title{
sciendo
}

\section{EFFECT OF CAPONISATION ON BONE DEVELOPMENT IN NATIVE MALE CHICKENS*}

\author{
Małgorzata Kwiecień ${ }^{1 \bullet}$, Kornel Kasperek ${ }^{2 *}$, Anna Winiarska-Mieczan ${ }^{1}$, Anna Danek-Majewska ${ }^{1}$, \\ Katarzyna Kwiatkowska ${ }^{1}$, Anna Arczewska-Włosek ${ }^{3}$, Łukasz Jarosz ${ }^{4}$, Eva Zaricka ${ }^{5}$ \\ ${ }^{1}$ Institute of Animal Nutrition and Bromatology, University of Life Sciences in Lublin, \\ Akademicka 13, 20-950 Lublin, Poland \\ ${ }^{2}$ Institute of Biological Basis of Animal Production, University of Life Sciences in Lublin, \\ Akademicka 13, 20-950 Lublin, Poland \\ ${ }^{3}$ Department of Nutrition Physiology, National Research Institute of Animal Production, \\ 32-083 Balice n. Kraków, Poland \\ ${ }^{4}$ Department of Epizootiology and Clinic of Infectious Diseases, University of Life Sciences in Lublin, \\ 20-612 Lublin, Poland \\ ${ }^{5}$ State Scientific-Research Control Institute of Veterinary Medical Products and Feed Additives, Lviv, \\ Ukraine \\ •Corresponding authors: malgorzata.kwiecien@up.lublin.pl; kornel.kasperek@up.lublin.pl
}

\begin{abstract}
The aim of the study was to determine the effect of caponisation on the morphometric traits and mechanical parameters of tibial and femoral bones in Greenleg Partridge cocks. The experiment involved 200 cocks. At the age of 8 weeks, 100 birds were subjected to surgical castration. At week 24, the birds were slaughtered and tibial and femoral bones were collected from 10 non-caponised cocks and 10 capons. The caponisation surgery had no effect on the weight and length of any of the long bones but resulted in reduction $(\mathrm{P} \leq 0.05)$ of the ash content in both bones and $\mathrm{Ca}$ in the femur. It also influenced the geometric structure of the bones, i.e. there was an increase $(P \leq 0.05)$ in the second moment of inertia in the tibial bone and the cross-sectional area and mean relative wall thickness in the femoral bone of the capons. The three-point bending test revealed a negative effect of caponisation on the mechanical strength of the bone. Values characterising the highest bone material strength, i.e. yielding load (femur), maximum force moment (tibia) and yielding deformation, bending point resistance, and load-to-deformation (both bones), declined in the capons. The investigations demonstrated a negative effect of caponisation on the quality of long bones. The tibial bone seems to be slightly more sensitive to the caponisation effects than the femoral bone. It can be assumed based on the analysis of biomechanical traits that the bones of capons are more susceptible to deformations or fractures due to their modified geometry and mechanical brittleness.
\end{abstract}

Key words: caponisation, cocks, bone characteristic, Greenleg Partridge breed

* Study funded from Statutory Research of Institute of Animal Nutrition and Bromatology, University of Life Sciences in Lublin, no. ZIZ/DS-4. 
The production of capons is deeply rooted in the local tradition of not only Asia but also Europe (Miguel et al., 2008; Díaz et al., 2010; Lin et al., 2012; Guo et al., 2015; Franco et al., 2016). They are mostly produced from native or locally adapted breeds with a slow growth rate. Similarly, conservative breeds, i.e. Greenleg Partridge, Yellowleg Partridge, and Polbar are used for the production of capons in Poland (Gryzińska et al., 2012, 2013; Kwiecień et al., 2015, 2018; Sokołowicz et al., 2016; Gesek et al., 2017).

Castration is a hormonal intervention, which permanently influences metabolic processes in birds (Rikimaru et al., 2011; Symeon et al., 2013; Chen et al., 2014). Androgen deficiency induces changes in birds' behaviour, and maturity regresses to the pre-caponisation stage (Chen et al., 2005). Androgens exert strong anabolic effects in various tissues, stimulating muscle, bone, and connective tissue growth (Pederson et al., 1999). Capons are usually reared for up to 6 months; hence, they must have a strong skeleton to support the growing body weight. As shown in many investigations, caponisation influences production results (Chen et al., 2006 a; Murawska and Bochno, 2007; Calik et al., 2015; Gesek et al., 2017; Kwiecień et al., 2015, 2018), blood parameters (Lin and Hsu, 2011; Cheng-Yung et al., 2012), and bone quality (Mahmud et al., 2014; Muszyński et al., 2017; Tomaszewska et al., 2017; Zawacka et al., 2018).

Induced by various factors (chemicals, testectomy operation, or age), androgen deficiency has a negative effect on bone growth and development in humans (Manolagas et al., 2002). In turn, the effects of castration on bone parameters in poultry are ambiguous. In poultry, unfavourable changes are most frequently observed in the tibial bone. Many studies have been focused on measurements of the length, weight, or outer surface of bones, but there are no reports on bone biomechanics and histology. Investigations conducted by Chen et al. (2014) demonstrated the impact of castration on the weight, length, and histological parameters of bones. Other studies (Muszyński et al., 2017) showed lower breaking strength of tibiotarsal bones in capons. Similarly, Tomaszewska et al. (2017) demonstrated that caponisation reduced mineral density and mechanical strength of femoral bone. Reduced tibial bone breaking strength after castration was also reported by Chen et al. (2007), Chen et al. (2014) and Lin et al. (2012). In turn, other studies did not show an effect of this treatment on bone parameters (Mahmud et al., 2014). The age and sex of birds were found to have a significant impact on bone tissue parameters during postnatal development (Charuta et al., 2012, 2013). A decline in the volumetric mineral density of tibiotarsal bones was demonstrated in 4-week-old broiler cocks (Charuta et al., 2013) and in 9-week-old turkeys (Charuta et al., 2012).

Sex steroid hormones have a substantial impact on bone metabolism; yet, the paracrine mediators of the androgen effect on bones are not fully known. There are not many reports on the effect exerted by androgens on the quality of bones in native breeds in Poland (Muszyński et al., 2017; Tomaszewska et al., 2017). Since other studies report a reduction in the weight, length, or biomechanics of bones in capons in comparison with non-caponised roosters, the present study assumes that, through the decrease in testosterone levels, the castration treatment of Greenleg Partridge cocks may also reduce bone structural integrity, inhibiting bone development. To obtain information on this issue, the investigations were focused on determination 
of the effect of caponisation performed at 8 weeks of age on the physicochemical, morphometric (geometric and cortical), and strength parameters of tibia and femur in Greenleg Partridge chickens.

\section{Material and methods}

All procedures used during the study were approved by the Local Ethics Committee for Animal Testing at the University of Life Sciences in Lublin, Poland (Approval No. 33/2013 of 16 April 2013).

\section{Experimental design}

The experiment was conducted on 200 Greenleg Partridge (old traditional Polish chicken breed) cockerels, which were individually weighed and labelled. One-dayold birds were weighed, marked with wing tags, and randomly distributed to pens. A hundred 8-week-old birds were surgically castrated by a qualified veterinarian in accordance with Commission Regulation (EC) No. 543/2008, as described in detail by Tomaszewska et al. (2017). Afterwards, the cocks were divided into two groups: control group - cocks ( 50 birds in 10 cages with 5 birds in each) and a caponised experimental group (50 birds in 10 cages with 5 birds in each). The birds were reared to 24 weeks of age, fed commercial diets ad libitum, and provided with continuous veterinary care. The feed mixes were prepared based on cereal meal middlings (maize, wheat, oat), post-extraction soya meal, and sunflower seeds (Table 1). Capons and non-caponised cocks were fed with standard complete feed mixes for general-purpose hens adequate for respective breeding periods (weeks 1-8, weeks 8-18, and over 18 weeks of life). The nutritive value of the diets is presented in Table 2 . The birds were kept in the same zoohygienic conditions.

Table 1. Composition $\left(\mathrm{g} \cdot \mathrm{kg}^{-1}\right)$ of the diet fed during the trial

\begin{tabular}{lcccc}
\hline \multicolumn{1}{c}{ Ingredients $\left(\mathrm{g} \cdot \mathrm{kg}^{-1}\right)$} & $1-8$ wk old & $8-18$ wk old & $>18$ wk old \\
\hline Corn & 441.5 & 438.0 & 281.9 \\
Wheat & 200 & 200 & 200 \\
Oat & 50 & 100 & 200 \\
Soybean meal & 200 & 100 & 100 \\
Sunflower meal & 50 & 100 & 150 \\
Soybean oil & 24 & 25 & 20 \\
Monocalcium phosphate & 13 & 14 & 19 \\
Limestone & 7.6 & 8.9 & 15 \\
NaHCO & 1.2 & 1.4 & 1.6 \\
$\mathrm{NaCl}$ & 2.7 & 2.7 & 2.5 \\
$\mathrm{Mineral-vitamin} \mathrm{premix}$ & $10^{*}$ & $10^{* *}$ & $10^{* * *}$ \\
\hline
\end{tabular}

*1 kg of premix for a period of 1-8 weeks contained: vit. A $12000 \mathrm{IU}$, vit. D $2500 \mathrm{IU}$, vit. E $25 \mathrm{mg}$, vit. $\mathrm{K}_{3} 3 \mathrm{mg}$, vit. $\mathrm{B}_{1} 2 \mathrm{mg}$, vit. $\mathrm{B}_{2} 6 \mathrm{mg}$, vit. $\mathrm{B}_{6} 5 \mathrm{mg}$, vit. $\mathrm{B}_{12} 0.02 \mathrm{mg}$, nicotic acid $30 \mathrm{mg}$, pantothenic acid $15 \mathrm{mg}$, folic acid $2 \mathrm{mg}$, biotin $0.2 \mathrm{mg}$, choline $700 \mathrm{mg}$, Fe $70 \mathrm{mg}$, Zn $60 \mathrm{mg}$, Mn $70 \mathrm{mg}$, Cu $8 \mathrm{mg}$, I $1 \mathrm{mg}$, Se $0.3 \mathrm{mg}$.

**1 kg of premix for a period of nine weeks from the end of the rearing contained: vit. A $10000 \mathrm{IU}$, vit. $\mathrm{D}_{3}$ $2000 \mathrm{IU}$, vit. E $25 \mathrm{mg}$, vit. $\mathrm{K}_{3} 2 \mathrm{mg}$, vit. $\mathrm{B}_{1} 2 \mathrm{mg}$, vit. $\mathrm{B}_{2} 4 \mathrm{mg}$, vit. $\mathrm{B}_{6} 4 \mathrm{mg}$, vit. $\mathrm{B}_{12} 0.02 \mathrm{mg}$, nicotic acid $25 \mathrm{mg}$, pantothenic acid $15 \mathrm{mg}$, folic acid $1 \mathrm{mg}$, biotin $0.2 \mathrm{mg}$, choline $300 \mathrm{mg}$, Fe $50 \mathrm{mg}$, Zn $50 \mathrm{mg}, \mathrm{Mn} 60 \mathrm{mg}, \mathrm{Cu}$ $7 \mathrm{mg}$, I $0.7 \mathrm{mg}$, Se $0.2 \mathrm{mg}$. 
Table 2. Nutrient composition of basal diet

\begin{tabular}{lcccc}
\hline \multicolumn{1}{c}{ Ingredients } & $1-8$ wk old & $8-18$ wk old & $>18$ wk old \\
\hline ME (MJ kg ${ }^{-1}$ ) & 11.20 & 11.30 & 11.00 \\
Crude protein (\%) & 17.32 & 15.24 & 16.72 \\
Crude fat (\%) & 4.00 & 4.00 & 3.40 \\
Crude fibre (\%) & 5.50 & 6.20 & 7.15 \\
Crude ash (\%) & 4.45 & 4.52 & 5.00 \\
Na (\%) & 0.18 & 0.18 & 0.17 \\
Ca (\%) & 1.00 & 1.30 & 4.00 \\
Available P (\%) & 0.35 & 0.32 & 0.40 \\
Lysine (\%) & 0.80 & 0.55 & 0.88 \\
Methionine (\%) & 0.30 & 0.25 & 0.35 \\
\hline
\end{tabular}

At the age of 24 weeks, 10 birds were selected from each group and slaughtered. During simplified dissection, tibial and femoral bones of the left leg of the birds were collected. Before slaughter, the birds did not receive feed but had permanent access to water. All birds were clinically healthy.

\section{Bone collection and analysis}

Carcasses were chilled for ca. $18 \mathrm{~h}$ at a temperature of $4^{\circ} \mathrm{C}$. Afterwards, tibias and femurs were collected, cleaned from soft tissue remnants, and subjected to basic measurements (bone weight and length). Relative bone weight was calculated from the ratio of bone mass to body weight. Based on the measurements, the bone density index was determined showing changes in bone mineralisation calculated as bone weight (in $\mathrm{mg}$ ) to length (in $\mathrm{mm}$ ) (Ziaie et al., 2011). This simple bone density index was introduced for the first time by Seedor et al. (1991). The higher the bone weight/length index, the denser is the bone and indicates changes in bone mineralization. After the measurements, the bones were wrapped individually in gauze soaked in physiological saline and kept frozen at a temperature of $-25^{\circ} \mathrm{C}$ for further analysis.

\section{Bone morphometric parameters}

The measurements of the external and internal horizontal and vertical diameter of the bone shaft cross-section at the fracture site performed with the use of a digital calliper were used for calculation of the following geometric parameters: cross-sectional area, the second moment of inertia and the mean relative wall thickness, thickness of the cortical layer, cortical surface, cortical index, and cortical parameters: the cortical surface index (Ferretti et al., 1993; Kwiecień et al., 2016; Tomaszewska et al., 2016).

\section{Bone mechanical properties}

The mechanical properties were determined after 3-hour thawing at room temperature. The three-point bending test of bone mid-diaphysis was performed on 
a Zwick Z010 universal testing machine (Zwick/Roell, Ulm, Germany). Prior to the analysis, the bone was placed horizontally on two rounded support bars. The distance between the supports was set in each case at $40 \%$ of the total bone length. The load was applied in the anterior-posterior plane of bone with a displacement rate of 10 $\mathrm{mm} \cdot \mathrm{min}-1$ until fracture. The maximum elastic strength and the ultimate strength were determined as described previously (Ferretti et al., 1993; Kwiecien et al., 2016; Tomaszewska et al., 2016). Based on the measurements, the strength parameters of bones were determined: the value of deflection, bending point resistance, and load-to-deformation ratio (Ferretti et al., 1993; Kwiecień et al., 2014). Additionally, the value of strength parameters of the tibial and femoral bones as well as the physical properties of the bone material determining its strength: yielding load towards bone weight, yielding load towards body weight, maximum force moment towards bone weight, and maximum force moment towards body weight were determined.

\section{Mineral composition of bones}

The femurs and tibias were defatted, dried to constant weight, and mineralised (AOAC, 2000). The Ca content was determined with atomic absorption spectrophotometry on the Unicam 939/959 apparatus, and total P was determined with the colorimetric method (Polish standard PN-76/R-64781, 1976) using the Helios a-Unicam apparatus with a molybdenum-vanadium reagent $\left(\mathrm{NH}_{4} \mathrm{VO}_{3},\left(\mathrm{NH}_{4}\right) 6 \mathrm{Mo} 7 \mathrm{O}_{2} 4 \cdot \mathrm{H}_{2} \mathrm{O}\right.$, $\mathrm{H}_{2} \mathrm{O}$ ) and converted into mineral content in crude ash.

\section{Blood analysis}

At 24 weeks of rearing, the birds were fasted for $10 \mathrm{~h}$ before blood sampling and slaughter. Plasma for analysis of the biochemical parameters was obtained by centrifugation of whole blood at $3000 \mathrm{rpm}(603 \times \mathrm{g})$ for $15 \mathrm{~min}$ in a laboratory centrifuge (MPW-350R; MPW Medical Instruments, Warsaw, Poland) at a temperature of $4^{\circ} \mathrm{C}$. Plasma without signs of haemolysis was analysed within $4 \mathrm{~h}$ after sampling and the contents of testosterone, the activity of alkaline phosphatase, and the contents of $\mathrm{Ca}$ and $\mathrm{P}$ were determined. Assays for the concentrations of plasma testosterone were carried out with an ELISA microtiter reader (MRX Dynex Technologies, USA), using ELISA kits (NEOGEN Testosterone ELISA kit, USA). The activity of the indicator enzyme, i.e. alkaline phosphatase, and the contents of $\mathrm{Ca}$ and $\mathrm{P}$ were determined in blood plasma with colorimetric methods using reagent kits according to the manufacturer's protocol (BioMaxima, Lublin, Poland; Hydrex Diagnostics, Warsaw, Poland) and a random access biochemical analyser Metrolab 2300 GL (Metrolab SA, Buenos Aires, Argentine). The analysis procedures were verified with the use of multiparametric control plasma (BioCal) as well as control plasma with a normal level (BioNorm) and a high level (BioPath) of indices (BioMaxima, Lublin, Poland; Hydrex Diagnostics, Warsaw, Poland).

\section{Statistical analysis}

The results tests were statistically analysed using Statistica software ver. 10 (Statsoft Inc., Tulsa, USA). The normality of data distribution was tested using the 
Shapiro-Wilk test. One-way analysis of variance was only used in the case of the assessment of the bone parameters, where the effect of the breed was examined:

$$
y i j k=\mu+\alpha i+e i j k
$$

where:

yijk - kth observation from the ith and jth groups,

$\mu$ - mean value of the trait in the population,

$\alpha i$ - effect of the ith group,

eijk - error $=$ effect related to individual variability and measurement error.

Significant statistical differences were set at the level of $\mathrm{P} \leq 0.05$. The significance of the differences between mean values in the respective diets was assessed using Duncan's multiple range test.

\section{Results}

\section{Physical properties and geometric characteristics of bones}

The caponisation surgery was shown to exert an impact on the final body weight, which was significantly higher in the capon group (Table 3). It did not change the weight of both bones; however, given the change in the final capon body weight, the proportion of the tibial and femoral bones in the body weight, i.e. the relative bone weight, decreased $(\mathrm{P} \leq 0.05)$ in the capons (Table 3 and 4$)$. The caponisation treatment did not change the femur and tibia length (Table 3 and 4). The value of the second moment of inertia was increased by approx. $14 \%(\mathrm{P}<0.05)$ in the femur (Table 4$)$ and by approx. $7 \%$ in the tibia of the capons (Table 3), with simultaneous reduction of the values of traits indicating the content of cortical tissue in the femur, i.e. the thickness of the cortical layer and the cortical surface (Table 3). Additionally, a ca. $7 \%$ and $12 \%$ increase in the cross-sectional area and mean relative wall thickness parameters, respectively, was noted in the femurs of the capons, in comparison with the non-caponised birds (Table 4).

\section{Mechanical properties of bones}

The caponisation treatment also exerted an effect on the femur and tibia strength parameters (Table 3 and 4). It led to a reduction of bone yielding load by $8.5 \%$, bending point resistance by $6.9 \%$, yielding deformation by $28 \%$, and load-to-deformation ratio by $17 \%$ in the capons' femur (Table 4 ). In turn, the value of the maximum force moment, bending point resistance, yielding deformation, and load-to-deformation ratio decreased by $12 \%, 25 \%, 12 \%$, and $23 \%$, respectively, in the tibial bone of the capons (Table 3). The value of the strength parameters of the bone material (i.e. yielding load towards body weight, maximum force moment towards bone weight, and maximum force moment towards body weight) in the femur was significantly lower $(\mathrm{P} \leq 0.05)$ in the capons (Table 3 and 4$)$. 


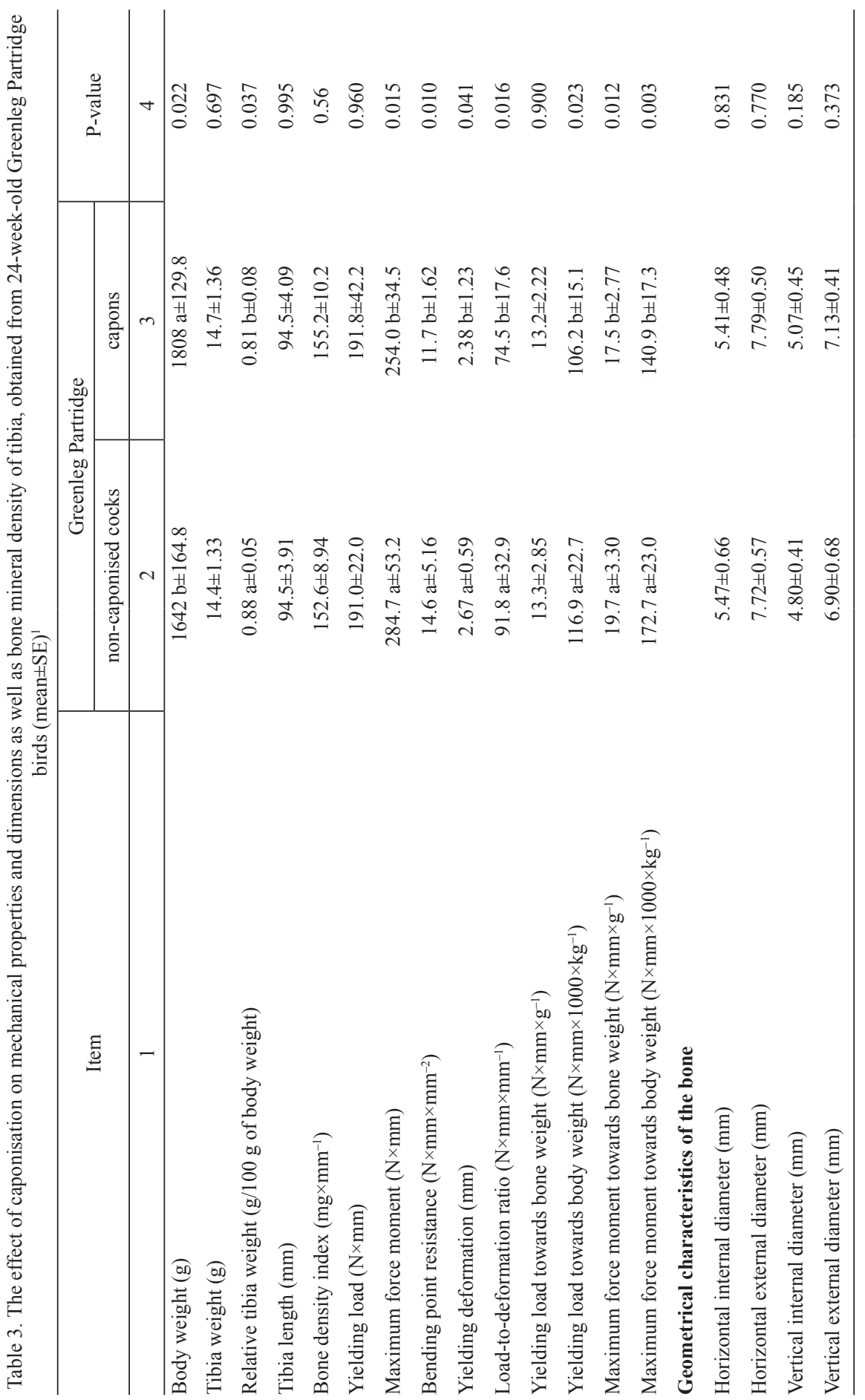




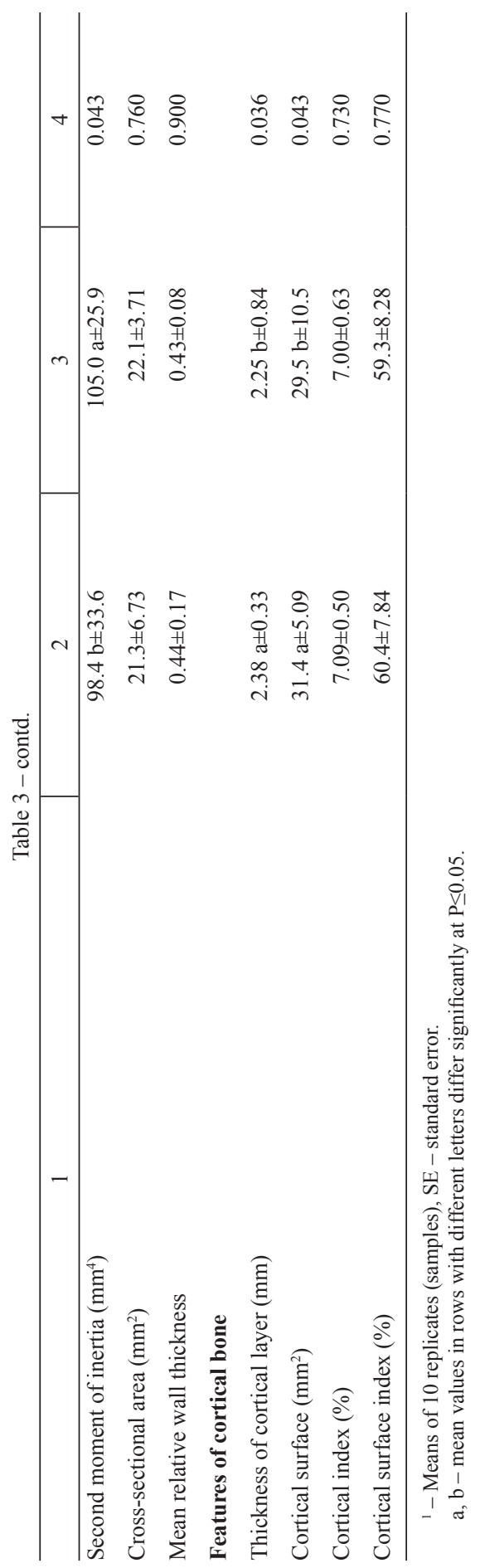




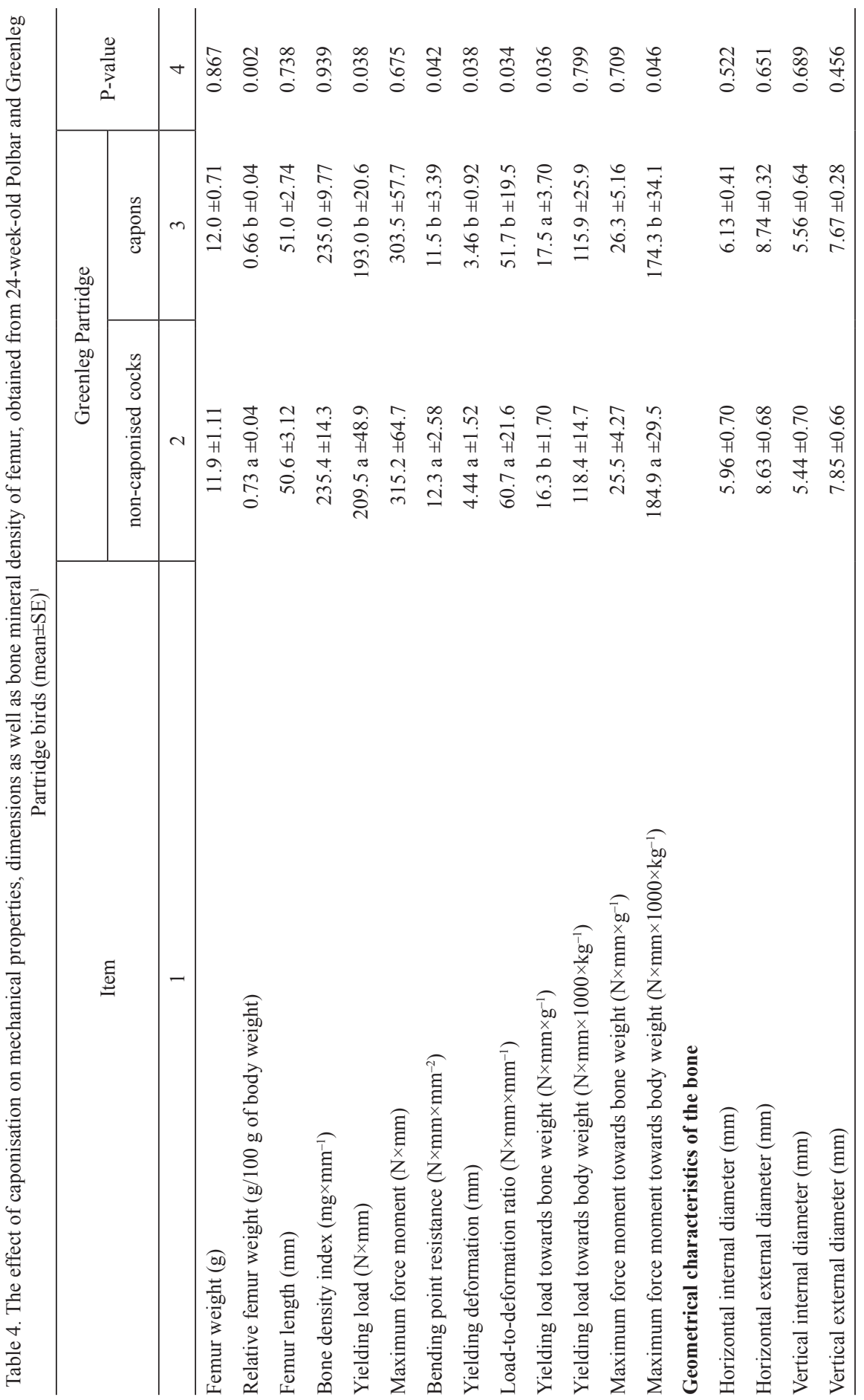




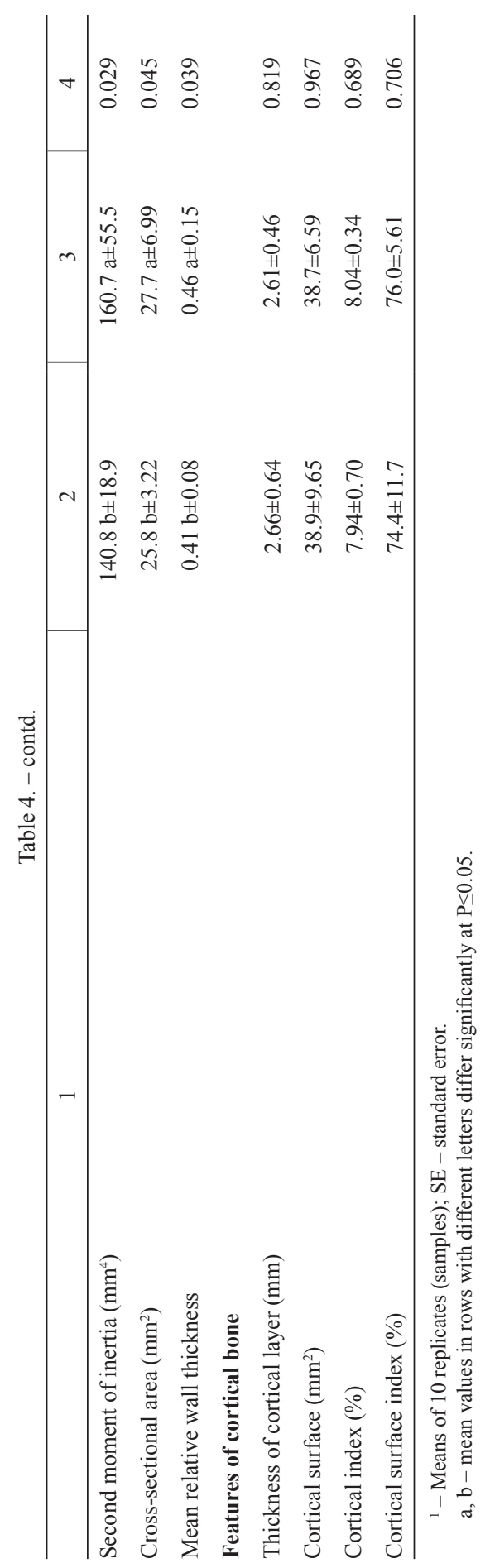




\section{Composition of bone minerals}

The ash content in both bones was significantly lower $(\mathrm{P} \leq 0.05)$ in the capons (Table 5). The caponisation surgery resulted in a $14 \%$ decline in the content of $\mathrm{Ca}$ in the femur $(\mathrm{P} \leq 0.05)$, whereas no effect of the treatment on the $\mathrm{P}$ content and the Ca:P ratio in both bones was detected (Table 5).

Table 5. Effect of caponisation on mineral composition of bones at 24 weeks (mean $\pm \mathrm{SE})^{1}$

\begin{tabular}{|c|c|c|c|}
\hline \multirow{2}{*}{ Item } & \multicolumn{2}{|c|}{ Greenleg Partridge } & \multirow{2}{*}{ P-value } \\
\hline & Non-caponised cocks & Capons & \\
\hline \multicolumn{4}{|l|}{ Tibia bone } \\
\hline Bone ash (\%) & $43.6 \mathrm{a} \pm 2.43$ & $40.6 \mathrm{~b} \pm 1.53$ & 0.004 \\
\hline $\mathrm{Ca}\left(\mathrm{g} \cdot \mathrm{kg}^{-1}\right)$ & $527.9 \pm 47.0$ & $512.2 \pm 14.5$ & 0.327 \\
\hline $\mathrm{P}\left(\mathrm{g} \cdot \mathrm{kg}^{-1}\right)$ & $185.1 \pm 7.73$ & $192.2 \pm 12.1$ & 0.135 \\
\hline $\mathrm{Ca}: \mathrm{P}$ & $2.85 \pm 0.05$ & $2,66 \pm 0.03$ & 0.537 \\
\hline \multicolumn{4}{|l|}{ Femur bone } \\
\hline Bone ash $(\%)$ & $39.8 \mathrm{a} \pm 1.93$ & $34.9 \mathrm{~b} \pm 1.58$ & $<0.001$ \\
\hline $\mathrm{Ca}\left(\mathrm{g} \cdot \mathrm{kg}^{-1}\right)$ & $552.5 \mathrm{a} \pm 61.3$ & $519.5 \mathrm{~b} \pm 32.1$ & 0.014 \\
\hline $\mathrm{P}\left(\mathrm{g} \cdot \mathrm{kg}^{-1}\right)$ & $189.5 \pm 0.92$ & $192.2 \pm 2.04$ & 0.052 \\
\hline $\mathrm{Ca}: \mathrm{P}$ & $2.91 \pm 0.06$ & $2.70 \pm 0.04$ & 0.421 \\
\hline \multicolumn{4}{|c|}{$\begin{array}{l}{ }^{1}-\text { Means of } 10 \text { replicates (samples); } \mathrm{SE} \text { - standard error. } \\
\mathrm{a}, \mathrm{b}-\text { mean values in rows with different letters differ significantly at } \mathrm{P} \leq 0.05 \text {. }\end{array}$} \\
\hline \multirow{2}{*}{ Item } & \multicolumn{2}{|c|}{ Greenleg Partridge } & \multirow{2}{*}{ P-value } \\
\hline & Non-caponised cocks & Capons & \\
\hline Testosterone (ng/ml) & $1.87 \mathrm{a} \pm 0.042$ & $0.17 \mathrm{~b} \pm 0.012$ & 0.004 \\
\hline $\mathrm{Ca}\left(\mathrm{mmol} \cdot \mathrm{l}^{-1}\right)$ & $2.76 \pm 0.22$ & $2.85 \pm 0.46$ & 0.327 \\
\hline $\mathrm{P}\left(\mathrm{mmol} \cdot \mathrm{1}^{-1}\right)$ & $1.59 \pm 0.14$ & $1.61 \pm 0.25$ & 0.135 \\
\hline Alkaline phosphatase $\left(\mathrm{U} \cdot \mathrm{l}^{-1}\right)$ & $681.5 \pm 221.3$ & $720.9 \pm 178.8$ & 0.781 \\
\hline
\end{tabular}

${ }^{1}$ - Means of 10 replicates (samples); SE - standard error.

$\mathrm{a}, \mathrm{b}-$ mean values in rows with different letters differ significantly at $\mathrm{P} \leq 0.05$.

\section{Level of testosterone, $\mathrm{Ca}, \mathrm{P}$, and activity alkaline phosphatase in the blood}

At 24 weeks of rearing, there was a 11-fold decrease in testosterone level in capon birds. There was a numerical tendency towards an increase in the level of $\mathrm{Ca}$ and $\mathrm{P}$ as well as alkaline phosphatase activity in the capons (Table 6).

\section{Discussion}

Caponisation of cocks is aimed at achievement of better weight gains and delicate-flavoured meat, which is a result of the increasing content of intramuscular 
fat (Hsieh et al. 2001). The results of our previous investigations of the Greenleg Partridge and Polbar conservative breeds demonstrated that surgical removal of testicles contributed to an increase in final body weight (Kwiecień et al., 2015; 2018). Similarly, higher capon body weight was reported in other studies (Chen et al., 2006 c; Chen et al., 2007; Calik et al., 2015; Adamski et al., 2016; Zawacka et al., 2017). Nevertheless, the results of the procedure and its effect on the body weight are contradictory. Investigations conducted by Shao et al. (2009) indicate a decrease in the weight of capons, while other studies show no significant effect of caponisation on the final weight (Symeon et al., 2010, 2012; Franco et al., 2016). This may be associated with the use of different bird breeds, changes in the rearing length, nutrition, or age at caponisation (Shao et al., 2009). The intense weight gain in capons, mainly the weight of muscles, is associated with heavy loads carried by birds' leg bones. Hence, the bones are more susceptible to developmental and mineralisation disorders, which in turn may lead to deformities and even fractures (Leterrier and Nys, 1992). The risk of bone fracture may be associated with such factors as age and sex (Charuta et al., 2012; Shim et al., 2012) as well as hormonal disorders induced by testectomy. Steroids are indispensable for the development, growth, and maintenance of the skeleton. It has been shown that the increasing testosterone concentration stimulates the activity of osteoclasts in bone formation, hence their key role in the development of the skeleton in growing cocks (Gryzińska et al., 2012). Additionally, androgens can promote proliferation and differentiation of osteoblasts, inhibit the recruitment of osteoclasts to osteoblasts, or influence calcium retention in bones, thereby accelerating their ossification (Falahati-Nini et al., 2000; Gryzińska et al., 2012). Investigations conducted by Lee et al. (2006) demonstrated increased bone resorption and reduced bone formation resulting from hypogonadal osteoporosis.

As expected, the testosterone concentrations in the plasma of intact male chickens increased significantly in the present study, which was confirmed in other studies (Chen et al., 2005; Zawacka et al., 2017). Our investigations demonstrated that the androgen deficiency in the capons (testosterone concentration of $0.17 \mathrm{ng} / \mathrm{ml}$ in the capons vs. $1.87 \mathrm{ng} / \mathrm{ml}$ in the non-caponised cocks) resulted in an increase in the abdominal fat (Kwiecien et al., 2015) and body weight by $10 \%$, compared with the non-caponised cocks. In contrast, it did not affect the bone weight and length, which may indicate that the skeleton growth in both groups was similar. However, in terms of the bone weight in relation to body weight, the relative bone weight in the capons was shown to be lower $(\mathrm{P} \leq 0.05)$. Similarly, the castration procedure described in other studies (Chen et al., 2006 b; Lin et al., 2012) did not influence the tibia weight but caused a reduction in the relative tibia weight. This indicates that tibial bones in caponised cocks must carry a greater weight load, which increases the risk of bone fracture. The caponisation-induced androgen deficiency changed the carcass tissue composition via intensification of anabolic processes and acceleration of the metabolic rate (Wink and Felts, 1980). However, it did not change the bone weight but reduced the bone proportions in the body weight. Therefore, the sex steroid deficiency during intensive skeletal development in young cocks may affect bone metabolism, resulting in bone loss and, consequently, osteoporosis. 
Alkaline phosphatase and $\mathrm{P}$ content in the blood can be indicators of bone traits. The bone cell contains large amounts of alkaline phosphatase released into the blood during bone growth or degeneration. It is also associated with osteogenic activity and the $\mathrm{P}$ concentration (Galvanovskii et al., 1985). However, in the present study, the alkaline phosphatase activity and the $\mathrm{P}$ content did not change $(\mathrm{P}>0.05)$. As demonstrated by Lin and Hsu (2003), phosphorus can be released from the bone and enter the blood after caponisation, resulting in an increase in phosphorus $(\mathrm{P}<0.05)$ in the blood of 26-week-old capons. In turn, Ca retention should increase with its increasing amount in the blood (Shafty et al., 1990). In the present study, there was no effect of castration at 8 weeks of age on the plasma $\mathrm{Ca}$ content in the cocks at rearing week 24.

Androgens can contribute to Ca retention in bones, thus accelerating bone ossification and increasing their weight and ash content. With age, the testosterone levels increase, and this mainly stimulates the activity of osteoclasts in bone formation (Anderson et al., 1998; Gryzińska et al., 2012). In our study, the caponisation procedure significantly reduced the ash content in both bones and reduced the Ca content in the femoral bones. In turn, it exerted no effect on the $\mathrm{P}$ content and the $\mathrm{Ca}: \mathrm{P}$ ratio. These results are in part consistent with the results reported by Chen et al. (2006 c) and Lin et al. (2012), which showed that caponisation reduced the ash content but did not change the Ca content. Another study (Lin and Hsu, 2003) demonstrated reduced Ca content in capons' bones, which did not influence the bone ash content. It can be assumed that the reduced content of bone ash and $\mathrm{Ca}$ in capons results from reduced deposition of $\mathrm{Ca}$ in bones caused by the deficiency of androgens (testosterone determining bone material maturity) induced by the caponization treatment (Mauras et al., 1999). Besides an inhibition or altered capacity of bone mineralization another possible interpretation is that bone turnover is increased (as suggested by increased alkaline phosphatase levels) and bone organic matrix does not have enough time to become fully mineralized (Rodriguez-Navarro et al., 2018).

Basically, the increased cross-sectional area of bone in capons is due to functional adaptation of bone to the increased weight of birds (Charuta et al., 2013). Although there were no statistical differences in our research, there was a tendency to increase the diameters (horizontal and vertical) of the cross-section at the bone fracture site in the capons, which was yet reflected in the geometric structure of the bones. The secondary moment of inertia and cross-sectional area of the femur increased, whereas only an increase in the secondary moment of inertia was noted in the tibial bone. The castration treatment induced a significant increase in the cortical layer thickness (mean relative wall thickness) in the femur, which determines the higher mechanical strength against applied forces. However, it did not affect the value of this trait in the tibial bone. Additionally, there was no impact of caponisation on the cortical index value. The castration procedure caused an increase in the medullary cavity, as confirmed by the increased diameters. The increase in the body weight of the capons increased the load and the mechanical wear of the bones.

Changes in mechanical parameters reflect alterations in bones occurring throughout life. Despite bone stiffness, bones exhibit some plasticity and flexibility and respond to the continuous or repetitive action of loading- and unloading-related 
deformation forces by changes in their structure (Malcolm, 2002). In the present investigations, the bones of the non-caponised cocks were less mature and had smaller diameters. In contrast, they were better mineralised, which probably contributed to the increase in the mechanical parameters of the femoral and tibial bones. The mechanical tests carried out in the present study revealed that the bones of the capons were more susceptible to the risk of deformation; moreover, there was a greater risk of permanent bone deformation in the capons, as the threshold value of the load resulting in plastic bone deformation decreased, which may lead to bone damage. The decline in the bone mechanical values after the caponisation surgery is consistent with the results reported by Chen et al. (2006 b). Furthermore, the caponisationinduced reduction of the testosterone level probably contributes to a decline in the weight of capons' leg muscles (Symeon et al., 2012; Kwiecień et al., 2015). Additionally, the present study showed that the values of most of the measured strength parameters of tibial bone and physical characteristics of the bone material determining bone strength, i.e. yielding load towards bone weight, yielding load towards body weight, maximum force moment towards bone weight, and maximum force moment towards body weight, were lower in the capons.

The discrepancies between the results of various studies may be associated with the differences in the bird material analysed. An important effect is also exerted by the concentration of hormones, e.g. testosterone. At post-caponisation week 4, increased bone loss occurs, which is manifested by damage to bone cells, indicating a reduction of relative bone weight, breaking strength, cortical layer thickness, and ash, $\mathrm{Ca}$, and $\mathrm{P}$ contents (Lin et al., 2012).

\section{Conclusions}

In conclusion, our study demonstrates that castration has an adverse effect on the structural integrity of tibial and femoral bones and inhibits their development. Based on the analyses, it can be concluded that the bones of capons are more susceptible to deformations or fractures, which is reflected in the lower values of their geometrical and mechanical parameters. It seems that the tibia, which is burdened by a higher body weight load, is more susceptible to the effects of caponisation than the femoral bone, which increases the risk of tibia fracture.

\section{Disclosure statement}

No potential conflict of interest was reported by the authors.

\section{References}

A d a m ski M., Kuźn i ck a J., B a n a s za k M., We g ner M. (2016). The analysis of meat of Sussex cockerels and capons (S11) at different ages. Poultry Sci., 95: 125-152.

And er s on F.H., Fran c is R.M., S e lby P.L., C o o p e r C. (1998). Sex hormones and osteoporosis in men. Calcif. Tissue Int., 62: 185-188.

AOAC (2000). Official Methods of Analysis of AOAC International, 17th Edition. International, Gaithersburg, MD, USA. 
Calik J., Połtowicz K., Świątkiewicz S., Krawczyk J., Nowak J. (2015). Effect of caponization on meat quality of Greenleg Partridge cockerels. Ann. Anim. Sci., 15: 541-553.

Charuta A., Dzierzę cka M., B ies ia da-Drzazga B. (2012). Evaluation of densitometric and geometric parameters of tibiotarsal bones in turkeys. Bull. Vet. Inst. Pulawy, 56: 379-384.

Charuta A., Dzierzęcka M., Komosa M., Kalinowski Ł., Pierzchała M. (2013). Age- and sex-related differences of morphometric, densitometric and geometric parameters of tibiotarsal bone in Ross broiler chickens. Folia Biologica (Krakow), 61: 211-220.

Ch en K.L., Chi W.T., Ch i o u P.W.S. (2005). Caponization and testosterone implantation effects on blood lipid and lipoprotein profile in male chickens. Poultry Sci., 84: 547-552.

Chen K.L., H s i e h T.Y., Ch i o u P.W.S. (2006 a). Caponization effects on growth performance and lipid metabolism in Taiwan country chicken cockerels. Asian-Aust. J. Anim. Sci., 19: 438-443.

Ch en K.L., Chang M.H., T s a y S.M., H u a n g H.Y., C h i o u P.W.S. (2006 b). Effects of caponization on bone characteristics and histological structure in chickens. Asian-Aust. J. Anim. Sci., 19: $245-251$.

Chen K.L., Ts a y S.M., L e e T.Y., Ch i o u P.W.S. (2006 c). Effects of caponization and different exogenous androgen on the bone characteristics of male chickens. Poultry Sci., 85: 1975-1979.

Chen K., Ts a y S., L o D., K u o F., W a n g J., Ch i o u P.W.S. (2007). Effects of caponization and testosterone on bone and blood parameters of SCWL male chickens. Asian-Aust. J. Anim. Sci., 20: $706-710$.

Chen S.Y., Li T.Y., Ts a i C.H., L o D.Y., Chen K.L. (2014). Gender, caponization and exogenous estrogen effects on lipids, bone and blood characteristics in Taiwan country chickens. Anim. Sci. J., 85: 305-312.

Cheng-Yung L., Jenn-Chung H., Tien-Chun W. (2012). Effect of age and caponization on blood parameters and bone development of male native chickens in Taiwan. Asian-Aust. J. Anim. Sci., 25: 994-1002.

Díaz O., Rodríguez L., Torres A., Cobos A. (2010). Chemical composition and physicochemical properties of meat from capons as affected by breed and age. Span J. Agric. Res., 8: 91-99.

Falahati-Nini A., Riggs B.L., Atkinson E.J., O'Fallon W.M., Eastell R., Khos l a S. (2000). Relative contributions of testosterone and estrogen in regulating bone resorption and formation in normal elderly men. J. Clin. Invest., 106: 1553-1560.

Ferretti J.L., Capozza R.F., Mondelo N., Z a n chetta J.R. (1993). Interrelationships between densitometric, geometric and mechanical properties of rat femora: inferences concerning mechanical regulation of bone modelling. J. Bone Min. Res., 8: 1395-1399.

Franco D., Pate iro M., R o is D., Vázquez J.A., L or enzo J.M. (2016). Effects of caponization on growth performance, carcass and meat quality of Mos breed capons reared in free-range production system. Ann. Anim. Sci., 16: 909-929.

Galvanovski i Y.Y., Val in i e t s e M.Y., B a u man V.K. (1985). Effect of vitamin D on the transport of inorganic phosphorus and activity of alkaline phosphatase in the small intestine of chickens. Fiziol. Zh. SSSR Im. I. M. Sechenova, 71: 243-247.

Ge se k M., Z aw a ck a M., M u raw s k a D. (2017). Effects of caponization and age on the histology, lipid localization, and fiber diameter in muscles from Greenleg Partridge cockerels. Poultry Sci., 96: 1759-1766.

Gryzińska M.M., Kra u ze M., Strachecka A. (2012). Ca(2+)-ATPase activity according to the sex and age of Polbar hens. Med. Weter., 68: 483-487.

Gryzińska M.M., Krauze M., K lebaniuk R., Stracheck a A. (2013). Influence of gender and age on haematological indicators of Polbar's breed chickens. Acta Vet-Beograd, 63: 601-608.

Guo X., Nan H., Shi D., Zhou J., Wan Y., Zhou B., Geng Z., Chen X., Ji ang R. (2015). Effects of caponization on growth, carcass, and meat characteristics and the mRNA expression of genes related to lipid metabolism in roosters of a Chinese indigenous breed. Czech J. Anim. Sci., 60: $327-333$.

H s i e h C.Y., C h e n K.L., C h i o u P.W.S. (2001). The lipoprotein composition and structure of capon and incomplete caponized Taiwan country chicken. Abstract. J. Chin. Soc. Anim. Sci., 30: 229.

Kwi e c i eń M., Wi n i ars ka-Mi e c zan A., Z aw iślak K., S rok a S. (2014). Effect of copper glycinate chelate on biomechanical, morphometric and chemical properties of chicken femur. Ann. Anim. Sci., 14: 127-139. 
Kwiecień M., Kasperek K., Grela E., Jeżewska-Witkowska G. (2015). Effect of caponization on the production performance, slaughter yield and fatty acid profile of muscles of Greenleg Partridge cocks. J. Food Sci. Tech. Mys., 52: 7227-7235.

Kwi ecień M., Winiarska-Mieczan A., Milczarek A., Tomaszewska E., Matra s J. (2016). Effects of zinc glycine chelate on growth performance, carcass characteristics, bone quality, and mineral content in bone of broiler chicken. Livest Sci., 191: 43-50.

Kwiecień M., Kasperek K., Tomaszewska E., Muszyński S., Jeżewska- Wi t k ow s k a G., W in i a r sk - Mi e c z a n A., Gre la E.R., K a m iń s k a E. (2018). Effect of breed and caponisation on the growth performance, carcass composition, and fatty acid profile in the muscles of Greenleg Partridge and Polbar breeds. Braz. J. Poultry Sci., 20: 583-594.

Lee H., Finkelstein J.S., Miller M., Comeaux S.J., Cohen R.I., Leder B.Z. (2006). Effects of selective testosterone and estradiol withdrawal on skeletal sensitivity to parathyroid hormone in men. J. Clin. Endocrinol. Metab., 91: 1069-1075.

L e t e r r i e r C., N y s Y. (1992). Composition, cortical structure and mechanical properties of chicken tibiatarsi: effect of growth rate. Brit. Poultry Sci., 33: 925-939.

L in C.Y., H s u J.C. (2003). Comparison of some selected growth, physiological and bone characteristics of capon, slip and intact birds in Taiwan country chicken cockerels. Asian-Aust. J. Anim. Sci., 16: 50-56.

L in C.Y., H s u J.C. (2011). Effect of surgical caponization on blood characteristics of male Taiwan country chickens. J. Taiwan Livest. Res., 44: 25-37.

L in C.Y., H s u J.C., Wan T.C. (2012). Effect of age and caponization on blood parameters and bone development of male native chickens in Taiwan. Asian-Aust. J. Anim. Sci., 25: 994-1002.

Mahmud M.A., Shaba P., Gana J., Yarubi Yis a H., Ndagimba R., Abduls a la m W., $\mathrm{Ndagi}$ S., A bubakar H.L. (2014). Osteometric effects of surgical caponisation on some long bones in cockerel chickens. Adv. Zool., 4 pp.

Ma l c $1 \mathrm{~m} \mathrm{A.} \mathrm{(2002).} \mathrm{Metabolic} \mathrm{bone} \mathrm{disease.} \mathrm{Curr.} \mathrm{Diag.} \mathrm{Pathol.,} \mathrm{8:} \mathrm{19-25.}$

Manolaga s S.C., Kou st en i S., Jilk a R.L. (2002). Sex steroids and bone. Recent. Prog. Horm. Res., 57: 385-409.

Mauras N., Hayes V.Y., Vieira N.E., Yergey A.L., O'Brien K.O. (1999). Profound hypogonadism has significant negative effects on calcium balance in males: A calcium kinetic study. J. Bone Min. Res., 14: 577-582.

Miguel J.A., Ciria J., A s enjo B., Calvo J.L. (2008). Effect of caponization on growth and on carcass and meat characteristics in Castellana Negra native Spanish chickens. Animal, 2: $305-311$.

Mur aw s k a D., B o c h n o R. (2007). Comparison of the slaughter quality of layer-type cockerels and broiler chickens. J. Poultry Sci., 44: 105-110.

Muszyński S., Kwieci eń M., Tomaszewska E., Świetlicka I., Dobrowolski P., K a s per e k K., J e ż ew s k a - Witk ow s k a G. (2017). Effect of caponization on performance and quality characteristics of long bones in Polbar chickens. Poultry Sci., 96: 491-500.

Pederson L., Kremer M., Judd J., Pascoe D., S pekberg T.C., Riggs B.L., Ours le r M.J. (1999). Androgens regulate bone resorption activity of isolated osteoclasts in vitro. P. Natl. Acad. Sci. USA, 96: 505-510.

Polish Standard PN-76/R-64781. (1976). Feed. Determination of phosphorus content (in Polish). Polish Committee for Standardization, Warsaw, Poland.

R i k i maru K., Tak ah a sh i H., N i chola s M.A. (2011). An efficient method of early caponization in slow-growing meat-type chickens. Poultry Sci., 90: 1852-1857.

Rodriguez-Navarro A.B., McCormack H.M., Fleming R.H., Alvarez-Lloret P., Romero-Pastora J., Dominguez-Gasca N., Prozorov T., Dunn I.C. (2018). Influence of physical activity on tibial bone material properties in laying hens. J. Struct. Biol., 201: $36-45$.

S e ed or J.G., Quartucc i o H.A., Thompson D.D. (1991). The bisphosphonate alendronate (MK-217) inhibits bone loss due to ovariectomy in rats. J. Bone Miner. Res., 6: 339-346.

Shafty T.W., Mcdonald M.W., P y m R.A.E. (1990). Effects of dietary calcium, available phosphorus and vitamin on growth rate food utilization, plasma and bone constituents and calcium and phosphorus retention of commercial broiler strain. Brit. Poultry Sci., 31: 587-602. 
S h a o Y., W u C., Li J., Z h a o C. (2009). The effects of different caponization age on growth performance and blood parameters in male Tibetan chicken. Asian J. Anim. Vet. Adv., 4: 228-236.

Shim M.Y., Karnuh A.B., Mitchell A.D., Anthony N.B., Pesti G.M., Aggrey S.E. (2012). The effects of growth rate on leg morphology and tibia breaking strength, mineral density, mineral content, and bone ash in broilers. Poultry Sci., 91: 1790-1795.

S o k ołow i c z Z., K r a w c zy k J., Ś wi ą t k i ew i c z S. (2016). Quality of poultry meat from native chicken breeds - a review. Ann. Anim. Sci., 16: 347-368.

Symeon G.K., Mantis F., Bizelis I., Kominakis A., Rogdakis E. (2010). Effects of caponization on growth performance, carcass composition, and meat quality of medium growth broilers. Poultry Sci., 89: 1481-1489.

Symeon G.K., Mantis F., Bizelis I., Kominakis A., Rogdakis E. (2012). Effects of caponization on growth performance, carcass composition and meat quality of males of a layer line. Animal, 6:2 023-2030.

Symeon G.K., Char ismiadou M., Mantis F., Bizelis I., Kominakis A., Rogdak is E. (2013). Effects of caponization on fat metabolism-related biochemical characteristics of broilers. J. Anim. Physiol. Anim. Nutr., 97: 162-169.

Tomaszewska E., Dobrowolski P., Kwiecień M., Wawrzyniak A., Burmańc z u k N. (2016). Comparison of the effect of a standard inclusion level of inorganic zinc to organic form at lowered level on bone development in growing male Ross broiler chickens. Ann. Anim. Sci., 16: 507-519.

Tomaszewska E., Kwiecień M., Muszyński S., Dobrowolski P., Kasperek K., Blicharski T., Jeżewska-Witkowska G., Grela E.R. (2017). Long-bone properties and development are affected by caponisation and breed in Polish fowls. Brit. Poultry Sci., 58: 312-318.

W in k C.A., F e $1 \mathrm{t} \mathrm{s}$ WJ.L. (1980). Effects of castration on the bone structure of male rats: a model of osteoporosis. Calcif. Tissue Int., 32: 77-82.

Z aw a ck a M., Murawska D., Ge se k M. (2017). The effect of age and castration on the growth rate, blood lipid profile, liver histology and feed conversion in Green-legged Partridge cockerels and capons. Animal, 11: 1017-1026.

Zaw ack a M., Murawska D., Charuta A., Gesek M., Mieszczański T. (2018). Selected morphometric parameters and mineral density of tibiotarsal bones in green-legged partridge cockerels and capons. Pol. J. Nat. Sci., 33: 49-58.

Zia ie H., Bashtani M., Karimi M., Torshizi A., Naee imipour H., F arhangfar H., $\mathrm{Ze}$ in ali A. (2011). Effect of antibiotic and its alternatives on morphometric characteristics, mineral content and bone strength of tibia in Ross broiler chickens. Global Vet., 7: 315-322.

Received: 2 IV 2019

Accepted: 22 VIII 2019 